\title{
ANALISIS SUHU PERMUKAAN LAUT DAN KLOROFIL-A UNTUK MENGETAHUI POTENSI IKAN DI DALAM FISHING GROUND PURSE SEINE MENGGUNAKAN DATA CITRA SATELIT AQUA MODIS LEVEL 3
}

\author{
SEA SURFACE TEMPERATURE AND CLOROPHYL-A ANALYSIS FOR DISCOVERING FISH \\ POTENTIAL IN PURSE SEINE FISHING GROUNDS USING AQUA MODIS SATELITE \\ IMAGING DATA LEVEL 3 \\ Zulham Abdullah, Yusrizal, Syarif Syamsuddin* \\ Teknologi Penangkapan Ikan, Sekolah Tinggi Perikanan Jakarta 12520, Indonesia \\ *Korespondesi Penulis: syarif.syamsudin@kkp.go.id
}

Diterima: 2 November 2018; diterima setelah perbaikan: 7 November 2018; Disetujui: 13 November 2018

\section{ABSTRAK}

\begin{abstract}
Perairan dan laut Indonesia sangat kaya akan sumberdaya perikanan. Potensi dan kekayaan laut Indonesia yang terutama adalah ikan. Potensi lestari sumberdaya ikan laut Indonesia sebesar 7,3 juta ton per tahun yang tersebar di perairan wilayah Indonesia. Seluruh potensi sumberdaya ikan tersebut, jumlah tangkapan yang di perbolehkan (JTB) sebesar 5,8 juta ton per tahun atau sekitar 80 persen dari potensi lestari, dan baru dimanfaatkan sebesar 5,4 juta ton pada tahun 2013 atau baru 93\% dari JTB, sementara total produksi perikanan tangkap (di laut dan di danau) adalah 5,863 juta ton. Potensi tersebut masih kurang optimal dianfaatkan oleh masyarakat Indonesia. Adanya citra satelit dengan sensor pendeteksi suhu permukaan laut dan klorofil-a bisa dimanfaatkan untuk mengoptimlkan hasil tangkapan di suatu kapal. Pelaksanaan penelitian ini dilaksanakan di atas kapal Purse Seine yang beroperasi di laut Jawa, laut Flores sampai dengan selat Makassar. Pengoperasian Purse Seine terdiri dari 4 tahap, tahap persiapan, yaitu tahap pengumpulan ikan dengan rumpon portabel dan lampu kapal, tahap pelingkaran jaring, dimulai dari menurunkan lampu atraktor dan kemudian jarring diturunkan melingkari lampu atraktor, setelah itu tali kerut,ditarik sehingga jarring menyerupai mangkok, terakhir adalah tahap penarikan jaring. Tetapi karena daerah penangkapan hanya berdasarkan kebiasaan menangkap di tempat tersebut jadi hasil tergantung pada kondisi saat penangkapan dilakukan. Maka dari itu diperlukanlah analisis fishing ground melalui satelit supaya bisa menemukan fishing ground yang lebih tepat, dengan menganalisis suhu permukaan laut (spl) dan klorofil-a. Hasil dari penelitian ini membuktikan bahwa variabel independen spl $\left(\mathrm{X}_{1}\right)$ dan klorofil-a $\left(\mathrm{X}_{2}\right)$ secara bersama- sama berpengaruh nyata terhadap hasil tangkapan (Y).
\end{abstract}

Kata kunci: Citra satelit, Klorofil- a, Suhu permukaan laut, Daerah penangkapan.

\section{ABSTRACT}

Indonesian sea and waters is so rich of fisheries resources. The principal potential and assets of Indonesian sea is fish. The potential sustainability yields of Indonesian sea water fish resources is about 7.3 milion tons per year spreaded through Indonesian waters. The existence of satellite imaging that built with sea surface temperature sensor detection and klorofil-a sensor detection on it, can be useable for optimalizing fishing yields on a fishing vessel. This observation was doing on a purse seiner vessel that operated around Java Sea, Flores Sea, until Makassar Strain. The operation of Purse Seine is about 4 step, preparation step, there is step to gather fish using portable Fish Attractor Devices (FADs) and lamp on the vessel, setting step, begin with attractor lamp set down to the sea, then purse seine set rounded the attractor lamp, after that purse line pulled until purse sine formed like a bowl. The last step is hauling. But, because of fishing ground just based on habit of fishing on that place, so the yield is depend on the condition when fising operation doing. So, need an analitycal fishing grounds through satellite so that can found suitable fishing ground, with analyzing sea surface temperature (sst) and chlorophyll-a. The result of this observation prove that dependent variable in this case sst $\left(X_{1}\right)$ and chlorophyll-a $\left(X_{2}\right)$ have real effect to independent variable or catching product $(Y)$. So, suitable fishing ground can be determined depend on both of dependent variable.

Keywords: Satelite image, Clorophyl- a, Sea surface temperature, Fishing ground

Copyright (C) JKPT Juni 2018

Analisis Suhu Permukaan Laut dan Klorofil-a ........Abdullah, et.al 


\section{PENDAHULUAN}

Perairan dan laut Indonesia sangat kaya akan sumberdaya perikanan. Potensi dan kekayaan laut Indonesia yang terutama adalah ikan. Potensi lestari sumberdaya ikan laut Indonesia sebesar 7,3 juta ton per tahun yang tersebar di perairan wilayah Indonesia dan perairan Zona Ekonomi Eksklusif Indonesia (ZEEI) (Komnas Kajiskan 2003 dalam PERMEN-KP/NO.45 Tahun 2015). Dari seluruh potensi sumberdaya ikan tersebut, jumlah tangkapan yang di perbolehkan (JTB) sebesar 5,8 juta ton per tahun atau sekitar 80 persen dari potensi lestari, dan baru dimanfaatkan sebesar 5,4 juta ton pada tahun 2013 atau baru 93\% dari JTB, sementara total produksi perikanan tangkap (di laut dan di danau) adalah 5,863 juta ton (PERMEN-KP/NO.45 Tahun 2015).

Teknologi penginderaan jauh atau remote sensing dapat digunakan untuk menentukan posisi daerah potensi ikan dengan mengidentifikasi beberapa indikator tingkat kesuburan perairan dan kelimpahan makan bagi ikan. Beberapa parameter yang sering dijadikan indikator tersebut adalah suhu permukaan laut. Suhu permukaan laut dapat diestimasi dengan teknik penginderaan jauh, dimana saat ini algoritma SPL tingkat akurasinya lebih dari 70\% (Zahroh dan Sukojo, 2016).

SPL dapat diperoleh dengan pengukuran langsung (in situ) atau menggunakan citra satelit penginderaan jauh. Sensor satelit penginderaan jauh mendeteksi radiasi elektromagnetik yang dipancarkan oleh permukaan laut untuk melihat fenomena sebaran SPL. Radiasi yang dipancarkan umumnya berupa radiasi inframerah jauh (biasa disebut juga sebagai inframerah thermal) dengan panjang gelombang antara $8-15 \mu \mathrm{m}$. Radiasi inframerah thermal ini dapat melewati atmosfer tanpa diserap oleh gas dan molekul air yang berada di atmosfer, karena pada panjang gelombang antara $8-14 \mu \mathrm{m}$ tersebut serapan yang terjadi di atmosfer cukup rendah. Sehingga, panjang gelombang inframerah thermal banyak digunakan untuk mendeteksi emisi permukaan sesuai dengan suhunya (Emiyati, et.al., 2014).

Kekuatan utama dari satelit observasi bumi memungkinkan untuk memonitor kedinamisan dari permukaan bumi dan menghitung perubahan nyata, tersebut menyediakan dasar untuk memahami kecenderungan temporer dan kesignifikanannya. Dalam menggunakan sensor satelit sebagai alat ukur sangatlah penting bahwa pengukuran dan jumlah yang diperkirakan menjadi representasi akurat dari lingkungan bumi saat pengmbilan gambar. Masalah ini dapat dipahami dengan 2 langkah, representasi dan faktor refleksi atau karakteristik emisi dari permukaan, dan inversi dari pengukuran tersebut secara fisk atau variabel permukaan negara lain. Langkah pertama yang tepat untuk masalah pengukuran yang termasuk sensor kalibrasi, koreksi atmosferik, dan efek geometris pada pengukuran yang dikirimkan dan hubungannya dengan radiasi dipantulkan atau dipancarkan oleh target yang menjadi perhatian. Langkah kedua melibatkan studi dinamis lanskap (Cihlar, et.al., 1998). Dalam melakukan penelitian kebanyakan data yang diambil adalah data yang berasal dari satelit AVHRR (Advance Very High Resolution Radiometer) dan juga MODIS (Moderate Resolution Imaging Spectroradiometer). Masing-masing memiliki kelebihan dan kekurangan tersendiri. Dalam hal ini penulis menggunakan satelit MODIS.

Kebanyakan aktivitas penangkapan ikan hanya memperhatikan faktor alam sesuai dengan naluri dan alat bantu yang seadanya. Maka dari itu adanya penelitian ini bertujuan untuk melihat potensi ikan apa yang cocok pada suatu kondisi suhu permukaan laut dan klorofil-a tertentu. Sehingga ikan tujuan utama lebih mudah untuk didapatkan dengan menginterlasikan keadaan alam dengan citra satelit. Tujuan dari penelitian ini adalah untuk menganalisis potensi ikan dalam suatu kondisi Suhu Permukaan Laut dan Klorofil-a tertentu. Mengetahui pola hidup ikan melalui media citra satelit. Mengetahui cara menentukan daerah penangkapan ikan berdasarkan citra satelit. 
Penelitian ini ditujukan pada ikan hasil tangkapan utama kapal purse seine di Pelabuhan Perikanan Pantai Bajomulyo, Kecamatan Juwana, Kabupaten Pati, Jawa Tengah yang beroperasi di laut Jawa, Laut Flores, dan Selat Makasar.

\section{BAHAN DAN METODE}

Penelitian dilaksanakan di atas KM. Arta Mina Samudra 01 di laut Jawa, Laut Floes, dan Selat Makasar. Adapun peralatan penelitian tersebut yang digunakan adalah sebagai berikut:

Tabel 1. Peralatan

Table 1. Material

\begin{tabular}{|l|l|l|}
\hline No & \multicolumn{1}{|c|}{ Peralatan } & \multicolumn{1}{c|}{ Kegunaan } \\
\hline 1 & Alat Tulis & $\begin{array}{l}\text { Digunakan untuk melakukan pencatatan selama melakukan kegiatan praktik } \\
\text { terutama pada saat melakukan pengumpulan data. }\end{array}$ \\
\hline 2 & Kamera & $\begin{array}{l}\text { Sebagai alat untuk mendokumentasikan semua kegiatan yang ada pada saat } \\
\text { melakukan peraktik. }\end{array}$ \\
\hline 3 & Komputer & $\begin{array}{l}\text { Digunakan untuk membuat hasil karya tulis dan juga memanfaatkan software } \\
\text { SPSS v.23 untuk mengolah data yang berupa analisis statistik. }\end{array}$ \\
\hline 4 & Data Sheet & $\begin{array}{l}\text { Digunakan untuk mempermudah dalam pengumpulan data selama melakukan } \\
\text { praktik. }\end{array}$ \\
\hline 5 & Handphone & Untuk mencatat kegiatan secara sementara ketika di lapangan. \\
\hline 6 & Data MODIS & $\begin{array}{l}\text { Data mentah dari Satelit untuk selanjutnya diolah menjadi data variabel } \\
\text { oseanografi. }\end{array}$ \\
\hline 7 & SeaDas & Mengolah data mentah satelit menjadi data suhu permukaan laut dan klorofil-a. \\
\hline 8 & Surfer 13 & Untuk membuat peta kontur sebaran klorofil-a dan suhu perukaan laut. \\
\hline 10 & SPSS & Untuk mengolah data dengan alogaritma korelasi \\
\hline
\end{tabular}

Metode praktik akhir ini dilaksanakan menggunakan studi korelasi dengan variabel penelitian yaitu suhu permukaan laut sebagai varabel $\left(\mathrm{X}_{1}\right)$ dan klorofil-a sebagai varabel $\left(\mathrm{X}_{2}\right)$. Kedua variabel bebas (independent) tersebut dikorelasikan dengan variabel tak bebas (dependent) (Y) atau jumlah hasil tangkapan. Menurut para ahli, studi korelasi adalah metode penelitian yang membandingkan dua variabel atau lebih yang membahas tentang sejauh mana hubungan variasi satu variabel dengan variabel lain. Tujuan metode tersebut adalah untuk menguji hipotesis, dengan menghitung koefisien korelasinya.

Setelah diketahui keeratan hubungan antara masing- masing variabel, maka diujilah variabelvariabel tersebut dengan regresi linear berganda. Uji regresi linear berganda dilakukan untuk meramalkan suatu keadaan (naik turunnya) variabel dependent jika variabel independent dimanipulasi (Sugiyono, 2005). Adapun pengolahan data adalah sebagai berikut:

Copyright (C) JKPT Juni 2018

Analisis Suhu Permukaan Laut dan Klorofil-a

.Abdullah, et.al a) Tahap sebelum pengambilan data di internet tentang cira satelit, yaitu mengadakan pengamatan dan penelitian pada operasi penangkapan ikan di PPP Bajomulyo dengan ikut melakukan kegiatan operasi penangkapan dengan kapal purse seine di PPP Bajomulyo. Ini dilakukan agar didapatkan data suhu permukaan laut dan hasil tangkapan ikan setiap melakuakan kegiatan penangkapan ikan.

b) Mengambil atau mengunduh data citra satelit di internet. Untuk selanjutnya diolah

c) Pengolahan data citra satelit menggunakan aplikasi "SeaDas" kemudian di dapatakan data klorofil

d) Pengolahan data suhu dan klorofil menggunakan aplikasi "Microsoft Excel"

e) Pembuatan desain kontur peta atau pengolahan data kontur peta menggunakan aplikas "surrfer $11 "$.

f) Analisis korelasi dan regresi data primer dan data sekunder dengan menggunakan aplikasi "SPSS". 
Analisis korelasi ganda digunakan sebagai langkah awal untuk mengetahui ada tidaknya hubungan antar variabel dalam Bustami (2005). Rumus korelasi ganda adalah:

$$
R_{X_{1} X_{2} Y}=\sqrt{\frac{r_{x_{1} Y}^{2}+r_{x_{2} Y}^{2}-2 \cdot r_{X_{1} Y} \cdot r_{X_{2} Y} \cdot r_{X_{I} X_{2}}}{1-r_{X_{1} X_{2}}^{2}}}
$$

Keterangan:

$$
\begin{array}{ll}
\mathrm{R}_{\mathrm{X}_{1} \mathrm{X}_{2} \mathrm{Y}} & =\text { Nilai koefisien korelasi ganda } \\
\mathrm{R} & =\text { Korelasi Pearson Product Moment } \\
\mathrm{X} 1 & =\text { Variabel Suhu Permukaan Laut } \\
\mathrm{X} 2 & =\text { Variabel Klorofil- } \alpha \\
\mathrm{Y} & =\text { Jumlah spesies ikan tertentu yang } \\
& \text { paling banyak tertangkap }
\end{array}
$$

Korelasi Pearson Product Moment diperoleh dari rumus:

$$
r=\frac{n \cdot\left(\sum X Y\right)-\left(\sum X\right)\left(\sum Y\right)}{\sqrt{\left(n \cdot \sum X^{2}-\left(\sum X\right)^{2}\right) \cdot\left(n \cdot \sum Y^{2}-\left(\sum Y\right)^{2}\right.}}
$$

" $r$ " memilki ketentuan $-1 \leq r \leq r$. Interprestasi koefisien korelasi nilai " $\mathrm{r}$ " dirangkum pada tabel berikut:

Tabel 2. Koefisien Korelasi

Table 1. Correlation coefficientsien

\begin{tabular}{|l|l|}
\hline $\begin{array}{l}\text { Interval } \\
\text { Koefisien }\end{array}$ & $\begin{array}{l}\text { Tingkat } \\
\text { Hubungan }\end{array}$ \\
\hline $0,00-0,199$ & $\begin{array}{l}\text { Sangat } \\
\text { rendah }\end{array}$ \\
\hline $0,20-0,399$ & Rendah \\
\hline $0,40-0,599$ & Cukup \\
\hline $0,60-0,799$ & Kuat \\
\hline $0,80-1,000$ & Sangat kuat \\
\hline
\end{tabular}

Setelah koefisien korelasi didapatkan kemudian dilakukan uji signifikasi korelasi ganda $\mathrm{X}_{1}$ dan $\mathrm{X}_{2}$ terhadap $\mathrm{Y}$, yang ditentukan dengan rumus $\mathrm{F}_{\text {hitung: }}$

$$
F_{\text {hitung }}=\frac{\frac{R^{2}}{k}}{\frac{\left(1-R^{2}\right)}{(n-k-1)}}
$$

$$
F_{\text {tabel }}=F_{(1-\alpha)([d b=k],[d b=n-k-1])}
$$

\section{Keterangan:}

$\mathrm{K}=$ Jumlah variabel bebas

$\mathrm{n} \quad=$ Jumlah sampel

$\alpha=0,01$ atau 0,05

Setelah $F_{\text {hitung }}$ didapatkan, kemudian dibandingkanlah dengan $F_{\text {tabel }}$ dengan menggunakan kaidah pengujian dimana jika $F_{\text {hitung }}$ $>\mathrm{F}_{\text {tabel}}$, maka signifikan sebaliknya, jika $\mathrm{F}_{\text {hitung }}<$ $F_{\text {tabel, }}$ maka tidak signifikan. Setelah korelasi diketehui maka dilanjutkan dengan anallisis pengaruh parsial variabel independent yaitu $\mathrm{spl}\left(\mathrm{X}_{1}\right)$ dan klorofil-a $\left(\mathrm{X}_{2}\right)$ terhadap variabel dependent yaitu hasil tangkapan (Y). Rumus regresi linear sederhana:

$$
t=\frac{\bar{x}_{1}-\bar{x}_{2}}{\sqrt{\frac{S_{1}^{2}}{n_{1}}+\frac{S_{2}^{2}}{n_{2}}-2 r\left(\frac{S_{1}}{\sqrt{n_{1}}}\right)\left(\frac{S}{\sqrt{n_{2}}}\right)}}
$$

Keterangan:

$\overline{\mathrm{x}}_{1}=$ Rata - rata sampel 1

$\overline{\mathrm{x}}_{2}=$ Rata - rata sampel 2

$\mathrm{s} 1=$ Simpangan baku sampel 1

s2 = Simpangan baku sampel 2

$\mathrm{s}_{1}^{2}=$ Varian sampel 1

$\mathrm{s}_{1}^{2}=$ Varian sampel 2

$\mathrm{r}=$ Koefisien korelasi dua sampel

$$
s=\sqrt{\frac{n \sum_{i=1}^{n} x_{i}^{2}-\left(\sum_{i=1}^{n} x_{1}\right)^{2}}{n(n-)}}
$$

Keterangan:

$\mathrm{S}=$ Standar deviasi

$\mathrm{xi}=$ Nilai $\mathrm{x}$ ke-i

$\mathrm{n} \quad=$ Jumlah sampel

dimana,

H0: variabel independen secara parsial tidak berpengaruh signifikan terhadap varibel dependen. $\mathrm{H} 1$ : variabel independen secara parsial berpengaruh signifikan terhadap variabel dependen. 
Dari hipotesis diatas diambilah kesimpulan atau keputusan dengan melihat hasil uji signifikasi dan uji t. Berikut adalah dasar pengambian keputusan jika probabilitasnya (nilai sig) $>0.05$ atau $-\mathrm{t}$ tabel $<\mathrm{t}$ hitung $<\mathrm{t}$ tabel maka $\mathrm{H} 0$ tidak ditolak dan jika probabilitasnya (nilai sig) $<0.05$ atau $\mathrm{t}$ hitung $<-\mathrm{t}$ tabel atau $\mathrm{t}$ hitung $>\mathrm{t}$ tabel maka $\mathrm{H} 0$ ditolak

Anallisis pengaruh parsial variabel independent yaitu spl $\left(\mathrm{X}_{1}\right)$ dan klorofil-a $\left(\mathrm{X}_{2}\right)$ terhadap variabel dependent yaitu hasil tangkapan (Y) sudah diketahui. Dilanjutkan dengan Anallisis pengaruh secara bersama - sama variabel independent yaitu spl $\left(\mathrm{X}_{1}\right)$ dan klorofil-a $\left(\mathrm{X}_{2}\right)$ terhadap variabel dependent yaitu hasil tangkapan (Y) sudah diketahui Rumus regresi linear berganda:

$$
\mathrm{Y}=\mathrm{a}+\mathrm{b}_{1} \mathrm{X}_{1}+\mathrm{b}_{2} \mathrm{X}_{2}
$$

Keterangan:

$\mathrm{X} 1=$ Variabel Suhu Permukaan Laut

$\mathrm{X} 2=$ Variabel Klorofil- $\alpha$

$\mathrm{Y}=$ Jumlah spesies ikan tertentu yang

$\mathrm{a}, \mathrm{b} 1, \mathrm{~b} 2=$ Konsanta

Persamaan di atas menggambarkan tingkat manipulatif data yang muncul ketika variable di manipulasi. Setelah persamaan diketahui maka dilakukanlah uji signifikasi, adapun hipotesis dalam uji signifikasi tersebut.

dimana,

H0: variabel independen secara bersama-sama tidak berpengaruh signifikan terhadap varibel dependen. $\mathrm{H} 1$ : variabel independen secara bersama-sama berpengaruh signifikan terhadap variabel dependen..

Dari hipotesis diatas diambilah kesimpulan atau keputusan dengan melihat hasil uji signifikasi dan uji t. Berikut adalah dasar pengambian keputusan jika probabilitasnya (nilai sig) $>0.05$ atau F hitung $<\mathrm{F}$ tabel maka H0 tidak ditolak dan jika probabilitasnya (nili sig) $<0.05$ atau $\mathrm{F}$ hitung $>\mathrm{F}$ tabel maka $\mathrm{H} 0$ ditolak.

Copyright (C) JKPT Juni 2018

Analisis Suhu Permukaan Laut dan Klorofil-a ........Abdullah, et.al

\section{HASIL DAN PEMBAHASAN}

Suhu Permukaan Laut Periode November Desember. Pada bulan November sampai dengan Desember di sekitar Selat Makassar dan Laut Flores jatuh pada musim barat. Musim barat adalah ketika massa air dari Laut Cina Selatan mendorong massa air yang ada di sekitar Selat Makassar sampai dengan Laut Flores. Maka suhu permukaan laut di sekitar Selat Makassar akan dipengaruhi suhu permukaan laut dari Laut Cina Selatan. Hasil pengambilan data secara langsung untuk variabel di perairan sekitar Selat Makassar dan Laut Flores pada tahun SPL pada bulan November - Desember 2017 , berkisar pada suhu $24-30^{\circ} \mathrm{C}$. Rata- rata SPL pada bulan tersebut adalah $27,9^{\circ} \mathrm{C}$. Berikut adalah tabel suhu permukaan laut selama bulan November - Desember.

Klorofil-a Periode November - Desember. Hasil citra satelit meperlihatkan bahwa kondisi klorofil-a perairan sekitar Selat Makassar dan Laut Flores pada tahun SPL pada bulan November - Desember 2017, berkisar pada 0,18490408 - 1,6794951 $\mathrm{mg} \cdot \mathrm{m}^{3}$. Rata- rata klorofil-a pada periode ini adalah $0,660565775 \mathrm{mg} \cdot \mathrm{m}^{3}$.

Analisis Korelasi. Hasil uji korelasi antara variabel suhu permukaan laut (X1) dan klorofil-a (X2) terhadap hasil tangkapan pada periode bulan November - Desember, berada pada angka 0,56. Angka tersebut menyatakan adanya hubungan antara variabel klorofil-a dan suhu permukaan laut terhadap hasil tangkapan, yang berada pada tingkatan cukup.

Analisis Regresi Linear Berganda. Setelah diketahui adanya hubungan antara variabel bebas (independent) dengan variabel tak bebas (dependent) maka diakukanlah analisis regresi untuk meramalkan suatu keadaan (naik turunnya) variabel dependent jika variabel independent dimanipulasi (Sugiyono, 2005). Dari hasil pengujian regresi linear berganda didapatkan persamaan sebagai berikut:

$$
Y=-1778.532+74.652 X_{1}+475.795 X_{2}
$$


Keterangan:

$\mathrm{X} 1$ = Variabel suhu permukaan laut

$\mathrm{X} 2$ = Variabel klorofil-a

$\mathrm{Y}=$ Jumlah spesies ikan tertentu yang paling banyak tertangkap

Persamaan di atas menggambarkan tingkat manipulatif data yang muncul ketika variabel di manipulasi. Tingkat manipulatif dalam alogaritma regresi tersebut adalah:

a) Setiap perubahan satu satuan $\mathrm{X} 1$ dan $\mathrm{X} 2$ adalah sebesar $-1228,085$ satuan.

b) Setiap perubahan 1 derajat pada spl (X1) mengakibatkan pertambahan sebesar 74.652pada hasil tangkapan (Y).

c) Setiap perubahan $1 \mathrm{mg} / \mathrm{m} 3$ pada klorofil-a (X2) mengakibatkan pertambahan sebesar 475.795 pada hasil tangkapan (Y).

Setelah persamaan diketahui maka dilakukanlah uji signifikasi, adapun hipotesis dalam uji signifikasi tersebut adalah didapatkan signifikasi sebesar 0,000 dan juga $F$ hitung sebesar 9.359. Setelah didapatkan signifikasi dan $\mathrm{F}$ hitung dicarilah $\mathrm{F}$ tabel dengan menghitung df (degree freedom)., didapatkanlah $\mathrm{F}$ tabel sebesar 3,20 (lampiran 4). Menurut dasar pengambilan keputusan, jika probabilitasnya (nili sig) $<0.05$ atau $\mathrm{F}$ hitung $>\mathrm{F}$ tabel maka $\mathrm{H} 0$ ditolak. Dalam hal ini hipotesis nol atau $\mathrm{H} 0$ adalah variabel independen secara bersama-sama tidak berpengaruh signifikan terhadap varibel dependen. Jadi variabel independen spl $\left(\mathrm{X}_{1}\right)$ dan klorofil-a $\left(\mathrm{X}_{2}\right)$ secara bersama-sama berpengaruh secara signifikan tehadap variabel depeden yaitu hasil tangkapan (Y).

Hubungan Suhu Permukaan Laut dengan Hasil Tangkapan. Hubungan suhu permukaan laut dengan hasil tangkapan ditunjukkan dengan angka 0,000 , yang berarti signifikan. Menurut asas pengambilan keputusan yaitu jika probabilitasnya (nilai sig) $<0.05$ atau $t$ hitung $>\mathrm{t}$ tabel maka $\mathrm{HO}$ ditolak. Maka ketika H0 ditolak otomatis H1 diterima. Sehingga SPL secara parsial berpengaruh sigifikan pada hasil tangkapan.

Berdasarkan uji korelasi SPL memiliki tingkat korelasi yang sangat rendah yatu pada angka koefisien korelasi 0,122. Disini menjadi pertanyaan mengapa SPL memiliki tingkat korelasi yang sangat rendah? Analisa terhadap hasil tangkapan spesifik suhu. Berikut grafik jumlah hasil tangakapan spesifik suhu.

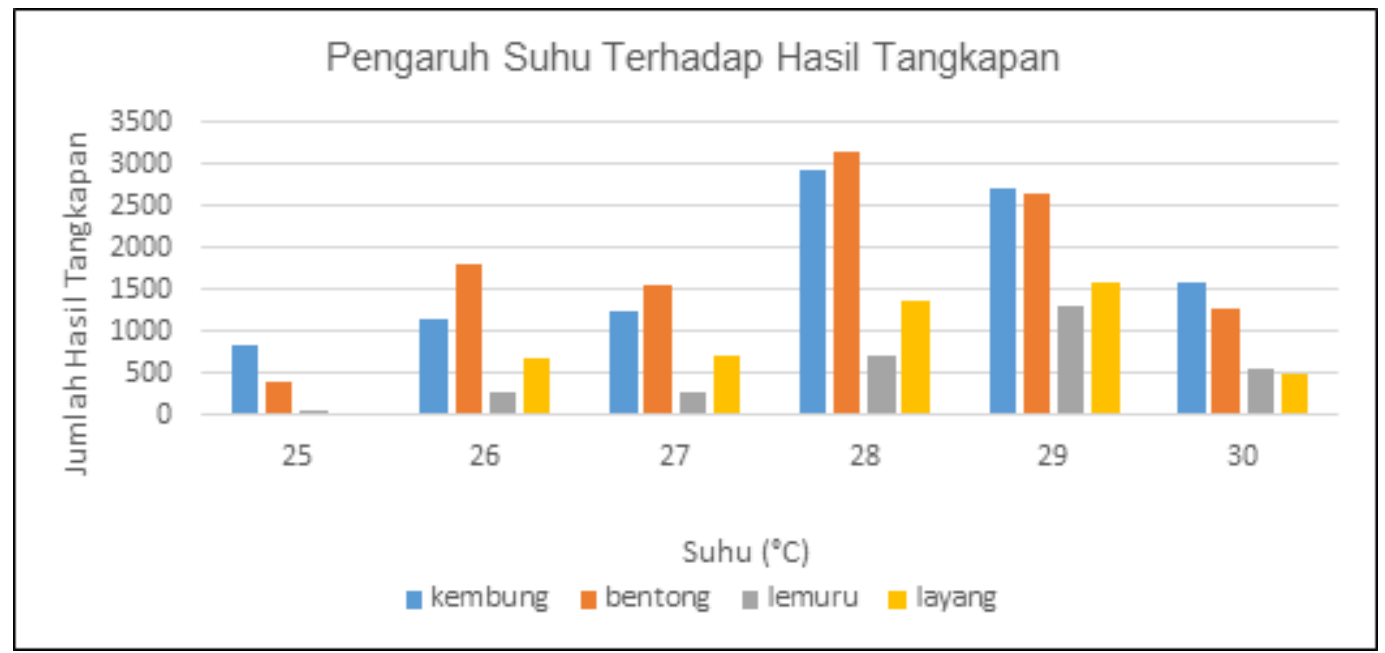

Gambar 1. Grafik Pengaruh Suhu terhadap Hasil Tangkapan

Figure 1. Graph of the Effect of Temperature on Catches

Hasil tangkapan terbesar adalah spesifik pada suhu $28-29{ }^{\circ} \mathrm{C}$. Ikan kembung dan bentong tangkapan terbanyak berada pada suhu $28^{\circ} \mathrm{C}$, dan untuk ikan lemuru dan layang tangkapan 
terbanyak berada pada suhu $29{ }^{\circ} \mathrm{C}$. Jadi ikan kembung dan bentong memiliki suhu spesifik yaitu pada suhu $28^{\circ} \mathrm{C}$ dan untuk ikan lemuru dan layang suhu spesifik berada pada suhu $29{ }^{\circ} \mathrm{C}$. Pernyataan tersebut diperkuat oleh Jamil S et al. (2010), Indawati T (2000) Safrudin (2013).

Hubungan Klorofil-a dengan Hasil Tangkapan. Hubungan klorofil-a dengan hasil tangkapan ditunjukkan dengan angka 0,035 yaitu signifikan. Menurut asas pengambilan keputusan yaitu jika probabilitasnya (nili sig) $<0.05$ atau $\mathrm{t}$ hitung $>\mathrm{t}$ tabel maka H0 ditolak. Maka ketika H0 ditolak otomatis H1 diterima. Sehingga klorofil secara parsial berpengaruh sigifikan pada hasil tangkapan. Berdasarkan hasil uji korelasi pada korelasi antara klorofil-a dan hasil tangkapan adalah cukup. Hal ini dibuktikan degan angka koefisien korelasi yang menunjukkan 0,469.

Penentuan Daerah Penangkapan Ikan. Hasil tangkapan yang sudah ada dari trip sebelumnya yang disertai suhu dan klorofil dikumpulkan. Selanjutnya akan dilakukan ananlisis kecocokan suhu dan klorofil-a terhadap hasil tangkapan. Kemudian dilakukanlah pemetaan suhu terhadap hasil tangkapan dan dianalaisis. Didapatkanlah suhu spesifik ikan kembung dan bentong yaitu $28^{\circ} \mathrm{C}$, untuk ikan layang dan lemuru suhu spesifik yaitu $29^{\circ} \mathrm{C}$ berdasarkan penelitian yang penulis lakukan. Setelah melakukan pemetaan suhu kemudian dilakukanlah pemetaan klorofil-a dan dilakukan analisis terhadap klorofil-a. Klorofil-a adalah variabel oseanografi yang kenaikannya berpengaruh signifikan terhadap hasil tangkapan. Dapat disimpulkan yaitu semakin banyak klorofila pada perairan maka semakin banyak ikan yang ada di dalamnya, berdasarkan data penelitian yang didapatkan (lampiran 4). Penentuan daerah penangkapan ikan dilakukan dengan dua cara yaitu pertama menentukan suhu spesifik ikan yaitu pada suhu $28-29{ }^{\circ} \mathrm{C}$. Dari beberapa titik yang memiliki spl antara $28-29^{\circ} \mathrm{C}$, dicarilah titik yang memiliki tingkat kadar klorofil terbesar.

\section{KESIMPULAN}

Hasil uji korelasi antara variabel klorofil-a dan suhu permukaan laut terhadap hasil tangkapan pada periode bulan November - Desember, berada pada angka 0,56. Angka tersebut menyatakan adanya hubungan antara variabel klorofil-a dan suhu permukaan laut terhadap hasil tangkapan, yang berada pada tingkatan cukup.

Hasil pengujian regresi linear berganda didapatkan persamaan sebagai berikut:

$$
\begin{aligned}
& Y=-1778.532+74.652 X_{1} \\
& +475.795 X_{2}
\end{aligned}
$$

Persamaan di atas menggambarkan tingkat manipulatif data yang muncul ketika variabel di manipulasi. Tingkat manipulatif dalam alogaritma regresi tersebut adalah:

a) Setiap perubahan satu satuan $X_{1}$ dan $X_{2}$ adalah sebesar -1228,085 satuan.

b) Setiap perubahan 1 derajat pada $\mathrm{spl}\left(\mathrm{X}_{1}\right)$ mengakibatkan pertambahan sebesar 74.652pada hasil tangkapan (Y).

c) Setiap perubahan $1 \mathrm{mg} / \mathrm{m}^{3}$ pada klorofila $\left(\mathrm{X}_{2}\right)$ mengakibatkan pertambahan sebesar 475.795 pada hasil tangkapan (Y).

Hasil uji signifikasi yaitu sebesar 0,000. Jadi variabel independen $\mathrm{spl}\left(\mathrm{X}_{1}\right)$ dan klorofil-a $\left(\mathrm{X}_{2}\right)$ secara bersama-sama berpengaruh secara signifikan tehadap variabel depeden yaitu hasil tangkapan (Y). Dalam kata lain bahwasanya perubahan spl $\left(\mathrm{X}_{1}\right)$ dan klorofil-a $\left(\mathrm{X}_{2}\right)$ akan mengakibatkan perubahan pada hasil tangkapan (Y). Ikan kembung dan bentong memiliki suhu spesifik yaitu pada suhu $28{ }^{\circ} \mathrm{C}$ dan untuk ikan lemuru dan layang suhu spesifik berada pada suhu $29{ }^{\circ} \mathrm{C}$. 


\section{DAFTAR PUSTAKA}

Bustami. DA dan Fadlisyah. 2014. Statistika Terapannya di Informatika. Graha Ilmu. Yogyakarta. 215 Hal.

Cihlar, J, Chen, J.M., Li, Z, Huang, F, Latifovic, R, dan Dixon, R. 1998. Can Interannual Land Surface Signal be Dicerned in Composite AVHRR Data?. Journal Of Geophysical Research Vol 103, NO. D18. Hal 23.163-23.172.

Emiyati, Setiawan. KT, Anneke KS. Manopo. A.K.S, Budhiman, S dan Hasyim, B 2014. Analisis Multitemporal Sebaran Suhu Permukaan Laut Di Perairan Lombok Mengunakan Data Penginderaan Jauh Modis. Seminar Nasional Penginderaan Jauh. Hal 470-479.

Indrawati. AT, 2000. Studi Tentang Hubungan Suhu Permukaan Laut Hasil Pengukuran Satelit Terhadap Hasil Tangkapan Ikan Lemuru (Srdinella lemuru Bleeker 1853). Institut Pertanian Bogor. 81 Hal.

Jamil. S, Marsoedi, Soemarno dan Sukoso, 2010. Penentuan Daerah Konsentrasi Ikan Kembung Lelaki (Rastrelliger kanagurta) dengan Menggunakan Model Kinesis di Perairan Pantai Barat Sulawesi Selatan. Jurnal Pembangunan dan Alam Lestari Vol. 1 No.1 Tahun 2010 No. ISSN. 2087 - 3522.
Safrudin, 2013. Distribusi Ikan Layang (Decapterus Sp) Hubungannya Dengan Kondisi Oseanografi Di Perairan Kabupaten Pangkep, Sulawesi Selatan. Torani (Jurnal Ilmu Kelautan dan Perikanan ) Vol. 23 (3) Desember 2013: 150 - 156.

Sugiyono. 2005. Memahami Penelitian Kualitattif. ALFABET. Bandung. $48 \mathrm{Hal}$

Zahroh. L, dan Sukojo, BM. 2016. Analisis Suhu Permukaan Laut untuk Penentuan Daerah Potensi Ikan Menggunakan Citra Satelit Modis Level 1B. Jurnal Teknik ITS. Surabaya Vol 5, No. 2. Surabaya. Hal 846849.

Kementrian Kelautan dan Perikanan (KKP). 2015. Permen KP RI No. 45/PERMEN KP/2015 tentang Perubahan atas Peraturan Menteri Kelautan dan Perikanan Republik Indonesia Nomor 25/PERMAN KP/2015 tentang Rencana Strategis Kementrian Kelautan dan Perikanan tahun 2015-2019. 